Agr. Biol. Chem., 40 (5), 927 933, 1976

\title{
Some Properties of Alkaline Protease in Rat Muscle Compared with That in Peritoneal Cavity Cells
}

\author{
Tadashi NoguchI and Makoto Kandatsu* \\ Department of Agricultural Chemistry, Faculty of Agriculture, \\ Iwate University, Morioka, Iwate, Japan \\ * Azabu Veterinary College, Fuchinobe, Sagamihara-shi, Kanagawa, Japan
}

Received November 7, 1975

\begin{abstract}
Further studies were made on muscle alkaline protease and, at the same time, its properties were compared with those of the protease in peritoneal cavity cells. Both enzymes showed similar properties. Their molecular weight was 22,000 , optimum temperature $57^{\circ} \mathrm{C}$, optimum pH $9.0 \sim 10.5$. They were slightly inhibited by soybean trypsin inhibitor. Tosylphenylalaninechloromethylketone inhibited both enzymes but tosyllysinechloromethylketone did not. Both enzymes cleaved peptide bonds Tyr (16)-Leu(17), Phe(24)-Phe(25) of oxidized $B$ chain of insulin.
\end{abstract}

In our previous paper, we reported purification and some properties of muscle alkaline protease. ${ }^{1 /}$ The enzyme was solubilized by $1.1 \mathrm{M} \mathrm{KI}$ and was inhibited by diisopropylfluorophosphate.

Several authors have reported the presence of a chymotrypsin-like protease in mast cells of peritoneal cavity ${ }^{2 \sim 6)}$ and thyroid tissue. ${ }^{7 \sim 9)}$ Since this protease shows similar properties to muscle alkaline protease, it is of interest to compare the properties of the two enzymes.

However, it was sometimes difficult to get sufficient mast cell protease to study its properties, as described by Pastan and Almquist. ${ }^{7)}$ It was also difficult to prepare a large amount of skeletal muscle protease in high purity, because skeletal muscle contains contractile proteins which give a very viscous solution during purification of muscle protease.

In the following experiments, we prepared sufficient muscle protease by the procedure described in the previous paper. ${ }^{1}$ We also prepared protease of peritoneal cavity cells by simple modification of the purification procedures of muscle alkaline protease.

In the present paper, further characterization of muscle alkaline protease and comparison with protease of peritoneal cavity cells will be reported.

\section{MATERIALS AND METHODS}

Muscle alkaline protease (MAP) was prepared as described previously, ${ }^{1)}$ except that extraction with sodium deoxycholate was omitted.

Peritoneal cavity cells were prepared according to Kawiak et al. ${ }^{5)}$ After washing cells with Hank's solution, the cells were dissolved in $1.1 \mathrm{M} \mathrm{KI}$ containing $6 \mathrm{mM} \mathrm{Na} \mathrm{Na}_{2} \mathrm{~S}_{2} \mathrm{O}_{3}$. This solution will be referred to as KI. The enzyme solution was fractionated directly with ice cold acetone, cooling in cracked ice. After adding the same volume of acetone to the enzyme solution in KI, the precipitate was removed by centrifugation. To the supernatant, a half volume of acetone (i.e., the same volume as the original enzyme solution) was further added to precipitate the enzyme. Almost all the activity was recovered in this fraction. The presipitated enzyme was dissolved in $\mathrm{KI}$ and used as the enzyme preparation. This preparation will be referred to as PCP.

Enzyme activity was determined as follows. Enzyme solution $(0.25 \mathrm{ml})$ was mixed with $0.25 \mathrm{ml}$ of water and $0.25 \mathrm{ml}$ of $1.5 \%$ casein solution in $150 \mathrm{~mm}$ glycine- $\mathrm{NaOH}$ (pH 9.2) buffer. After incubation for $30 \mathrm{~min}$ at $37^{\circ} \mathrm{C}$, the reaction was stopped by adding $1.25 \mathrm{ml}$ of $5 \%(\mathrm{w} / \mathrm{v})$ trichloroacetic acid. After standing overnight, the samples were filtered. Filtrate was diluted $2 \sim 8$ times with water according to enzyme activity in order to read the absorbance in the appropriate range. Folin's phenol reagent-positive material in the diluted filtrate was determined according to Lowry et al. ${ }^{10 \%}$ Activity was expressed as the increase in tyrosine equivalent of phenol reagent-positive material during incubation. 
Apparent molecular weight was determined on Sephadex G-75 and G-100 according to Andrews. ${ }^{11}$ Since muscle alkaline protease was hardly soluble in dilute buffers, the column was equilibrated with $\mathrm{KI}$. The effect of high concentration of KI on Sephadex was assumed to be negligible. Reference proteins were cytochrome c (Tokyo Kasei Chemical Co.), soybean trypsin inhibitor (Sigma Chemical Co.), chymotrypsin (Mochida Seiyaku Co.), ovalbumin (Sigma Chemical Co.) and $2 \mathrm{X}$ crystallized hemoglobin (Nutritional Biochemicals Co.). These reference proteins were chromatographed separately and elution volume was measured by its activity (soybean trypsin inhibitor, MAP, PCP and chymotrypsin) or its absorbance at $410 \mathrm{~nm}$ (cytochrome $c$ and hemoglobin) or at $280 \mathrm{~nm}$ (ovalbumin).

The effect of tosylphenylalaninechloromethylketone (TPCK) on proteolytic activity was examined as follows. Enzyme solution in $\mathrm{KI}(0.25 \mathrm{ml}), 0.25 \mathrm{ml}$ of $75 \mathrm{~mm}$ glycine- $\mathrm{NaOH}$ buffer (pH 9.2) and $0.05 \mathrm{ml}$ of TPCK in acetone were mixed and preincubated for $1 \mathrm{hr}$. Then $0.25 \mathrm{ml}$ of $1.5 \%$ casein solution in $75 \mathrm{~mm}$ glycine- $\mathrm{NaOH}$ buffer ( $\mathrm{pH}$ 9.2) was added and the remaining activity was determined by incubating the mixture for $30 \mathrm{~min}$ at $37^{\circ} \mathrm{C}$. Tosyllysinechloromethylketone (TLCK) was dissolved in $75 \mathrm{~mm}$ glycine- $\mathrm{NaOH}$ buffer ( $\mathrm{pH}$ 9.2). Preincubation was performed by mixing $0.25 \mathrm{ml}$ of this inhibitor solution and $0.25 \mathrm{ml}$ of enzyme solution. Other procedures were the same as those of TPCK.

The effect of soybean trypsin inhibitor on MAP, PCP and trypsin was studied as follows: $0.25 \mathrm{ml}$ of MAP, PCP or trypsin solution, $0.25 \mathrm{ml}$ of soybean trypsin inhibitor (Kunitz) dissolved in $15 \mathrm{mM} \mathrm{KH}_{2} \mathrm{PO}_{4}-$ $\mathrm{NaOH}(\mathrm{pH} 7.8$ ) and $0.25 \mathrm{ml}$ of $1.5 \%$ casein in $150 \mathrm{~mm}$ glycine- $\mathrm{NaOH}$ buffer (pH 9.2) were mixed and the enzyme activity was measured as described above. Trypsin was dissolved in $15 \mathrm{mM} \quad \mathrm{KH}_{2} \mathrm{PO}_{4}-\mathrm{NaOH}$ buffer ( $\mathrm{pH} 7.8$ ) or in $\mathrm{KI}$. There was no difference between the results in whichever solution trypsin was dissolved. MAP or PCP was used as KI solution.

The effect of $\mathrm{pH}$ and temperature on MAP and PCP was determined as described previously. ${ }^{1}$ However, $150 \mathrm{~mm}$ buffer was used instead of $15 \mathrm{~mm}$ buffer in pH-activity curve studies.

Oxidized B chain of insulin was prepared as follows. Six hundred and fifty $\mathrm{mg}$ of insulin (Shimizu Seiyaku Co.) was suspended and dissolved in $10 \mathrm{ml}$ of $0.01 \mathrm{M}$ acetic acid and a large volume of acetone was added to precipitate insulin. This procedure was repeated three times. The final precipitate was washed with acetone. Washed insulin was oxidized according to Baldwin and Riggs. ${ }^{13)}$ After washing with ether, the oxidized insulin was suspended in $12 \mathrm{ml}$ of water. Ammonia $(0.5 \mathrm{~N})$ was added dropwise and the oxidized insulin was dissolved. B chain was prepared according to Sanger. ${ }^{14)}$ Amino acid analysis of B chain preparation showed that contamination of $\mathbf{A}$ chain was negligible but about $10 \%$ of tyrosine in B chain was destroyed during oxidation and fractionation.

Action of MAP and PCP on oxidized B chain of insulin was studied as follows. Oxidized $\mathrm{B}$ chain was dissolved in $150 \mathrm{~mm} \mathrm{NaHCO}{ }_{3}-\mathrm{NaOH}$ buffer (pH 9.5) and stored in a freezer (approximately $-20^{\circ} \mathrm{C}$ ). One $\mathrm{ml}$ of this solution contained $9.6 \mathrm{mg}$ of oxidized B chain as measured by its amino acid composition (leucine was employed as the reference amino acid for calculation). Three $\mathrm{ml}$ of this $\mathrm{B}$ chain solution, $3 \mathrm{ml}$ of enzyme solution and $3 \mathrm{ml}$ of water were mixed and incubated for $3 \mathrm{hr}$ at $37^{\circ} \mathrm{C}$. One $\mathrm{ml}$ of the enzyme solutions showed $800 \mu \mathrm{g}$ tyrosine equivalents per $30 \mathrm{~min}$ incubation, using casein as the substrate. Time course of the release of ninhydrin-positive material during incubation was determined according to Yemm and Cooking. ${ }^{15)}$ After $3 \mathrm{hr}$ of incubation, the reaction was stopped by adding $9 \mathrm{ml}$ of $0.1 \mathrm{~N} \mathrm{HCl}$. The hydrolyzates were deionized on a Dowex $50 \mathrm{~W} \times 2$ column ( $H$ type, $1 \times 10 \mathrm{~cm}$ ) and eluted with $18 \%$ pyridine solution. The eluates were evaporatd in vacuo and dissolved in $5 \mathrm{ml}$ of water. Four $\mathrm{ml}$ of this solution was charged onto a Dowex $50 \mathrm{~W} \times 2$ column (pyridine type, $2.2 \times 23 \mathrm{~cm}$ ) equilibrated with $0.8 \%$ pyridine $-1.5 \%$ acetic acid as described by Titani and Yaoi. ${ }^{18)}$ Peptides were eluted by stepwise elution according to Titani and Yaoi. ${ }^{18)}$ Details of elution schedule are shown in the figure. A half $\mathrm{ml}$ of the fractions was sampled and ninhydrin-positive materials were detected according to Yemm and Cooking. ${ }^{16)}$ The fractions shown in the figure were pooled, evaporated in vacuo and dissolved in water. A small amount of $1 \mathrm{~N}$ acetic acid was added to dissolve the peptides if necessary. Amino acid composition was determined by a JEOL 5AH amino acid analyzer after hydrolysis of the peptides in $6 \mathrm{~N} \mathrm{HCl}$ at $105^{\circ} \mathrm{C}$ for $24 \mathrm{hr}$ in sealed tubes.

Dinitrophenylation of peptides was performed according to Iwai and Fujioka ${ }^{17}$ by dissolving peptides in triethylamine.

Thin-layer chromatography was performed by the usual method using $20 \times 20 \mathrm{~cm}$ plates which were not activated. Silica gel layer (Wakogel B-10, Wako Chemical Co.) was approximately $0.3 \mathrm{~mm}$ thick, and developing solvent was butanol-acetic acid-water (4:1:1).

\section{RESULTS}

\section{Apparent molecular weight of MAP and PCP}

MAP showed apparent molecular weight of 22,000 on Sephadex G-75 chromatography (Fig. 1). MAP and PCP showed the same effluent volume on Sephadex G-100 (Fig. 2). 
This means that the apparent molecular weight of PCP is also 22,000. This value accords well with that of Pastan and Almquist. ${ }^{\text {) }}$

\section{Inhibition of MAP and PCP by soybean trypsin inhibitor}

MAP was considerably less sensitive to inhibition by soybean trypsin inhibitor compared with trypsin (Fig. 3). The possibility that this slow inhibition is due to the low molecular activity of MAP was discounted, since MAP was sensitive to inhibition by protease inhibitor in skeletal muscle or in the serum of rats. ${ }^{12}$ PCP was inhibited by soybean trypsin inhibitor in similar manner to MAP.

The effect of TPCK and TLCK on MAP and $P C P$

PCP and MAP were inhibited by TPCK as shown in Table I. TLCK did not inhibit either enzyme at the concentration indicated in the table. The effect of TPCK on PCP is consistent with other studies. ${ }^{5}$

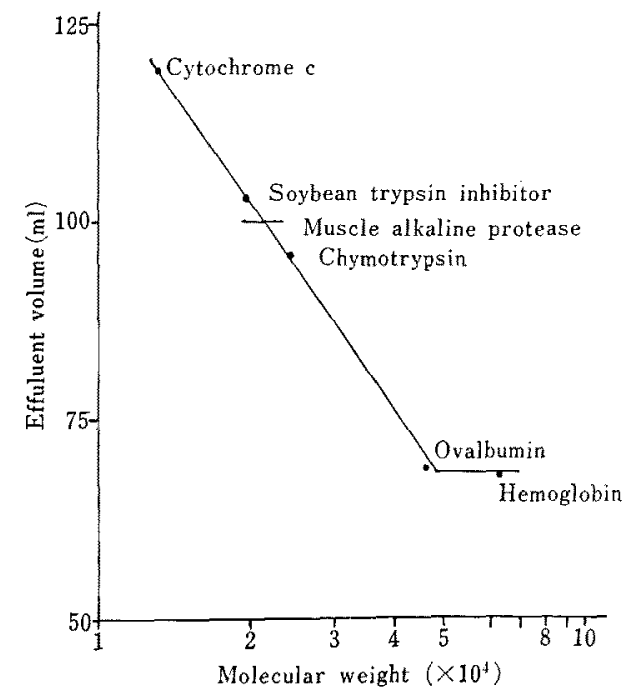

FIG. 1. Apparent Molecular Weight of MAP on Sephadex G-75.

The proteins other than MAP were chromatographed in $50 \mathrm{~mm} \mathrm{KH} \mathrm{KO}_{4}-\mathrm{NaOH}(\mathrm{pH} 7.7$ ) on a Sephadex G-75 column $(2.5 \times 31 \mathrm{~cm}$, bed volume $153 \mathrm{ml})$. MAP was chromatographed in KI. The proteins were detected by their activity or by their absorbance as described in Materials and Methods.

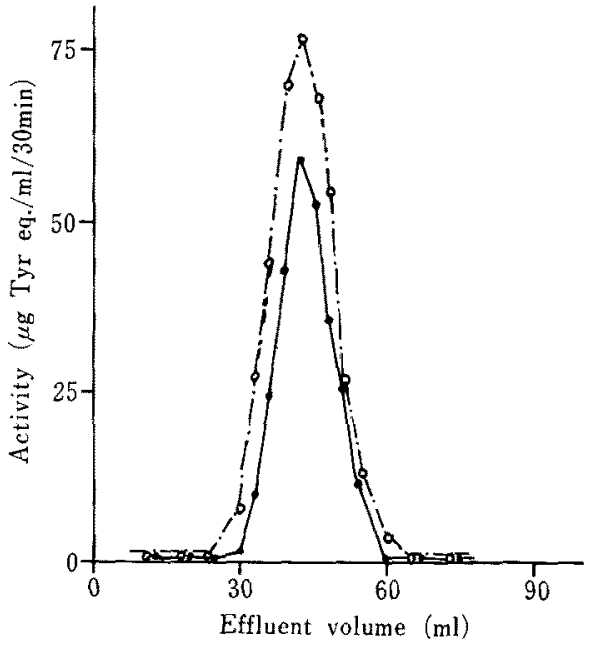

FIG. 2. Sephadex G-100 Chromatography of MAP and PCP.

A Sephadex G-100 column $(2 \times 20 \mathrm{~cm}$, bed volume $60 \mathrm{ml}$ ) was equilibrated with $1.1 \mathrm{M} \mathrm{KI}$. Five $\mathrm{ml}$ of enzyme solution was charged onto the column. Fractions of $3 \mathrm{ml}$ were collected and the enzyme activity was determined as described in MATERIALS AND METHODS.

- - PCP; O-O, MAP.

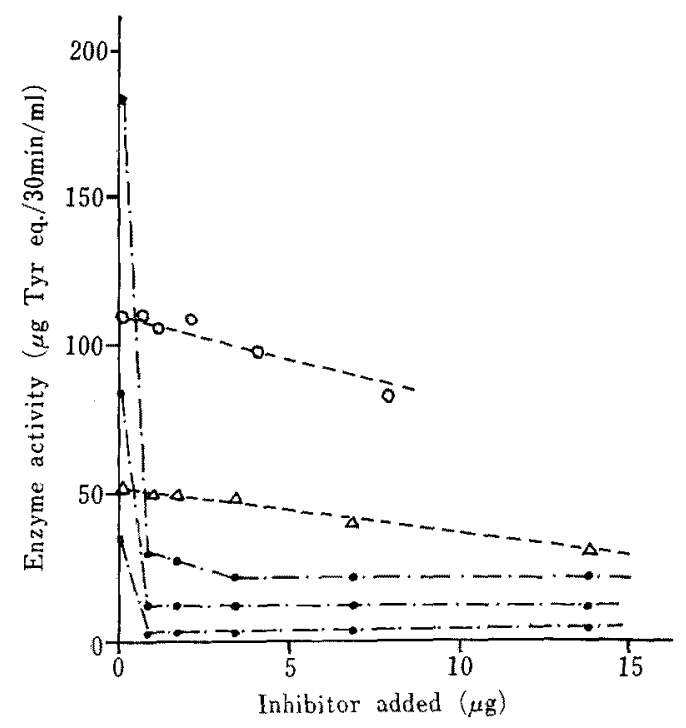

FIG. 3. Inhibition of MAP, PCP and Trypsin by Soybean Trypsin Inhibitor.

The details of the experiment are described in Materials and Methods.

--.--e, trypsin; O--O, MAP; $\triangle--\triangle$, PCP. 
TABLE I. EFFECT OF TPCK AND TLCK ON MAP AND PCP

Enzymes were preincubated for $1 \mathrm{hr}$ in the presence of TPCK or TLCK and in the absence of substrate. Remaining activity was determined as described in Materials AND Methods. In the case of TPCK, $100 \%$ activity of MAP and PCP was 151 and $161 \mu \mathrm{g}$ tyrosine equivalent per $30 \mathrm{~min}$ per $\mathrm{ml}$ of enzyme solution respectively. In the case of TLCK, it was 213 (MAP) and 207 (PCP).

Enzyme activity

( $\%$ of control without inhibitor)

\begin{tabular}{lccc} 
Inhibitor & Concentration & \multicolumn{2}{c}{ Activity } \\
\hline \multirow{2}{*}{ TPCK } & $(\mathrm{mM})$ & MAP & PCP \\
& 0.5 & 74 & 67 \\
TLCK & 0.05 & 90 & 90 \\
& 0.5 & 97 & 97 \\
\hline
\end{tabular}

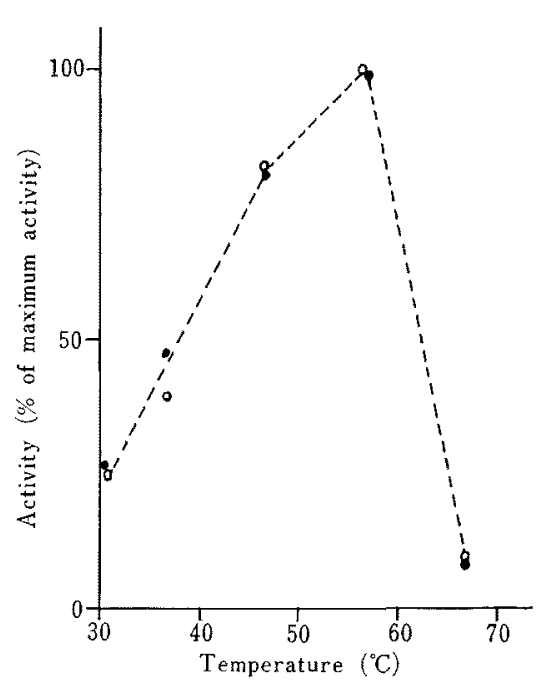

FIG. 4. Temperature-Activity Curve of MAP and PCP.

The enzyme activity was determined according to Noguchi and Kandatsu, ${ }^{13}$ in the presence of $2 \%$ casein as the substrate. Maximum activity of MAP and PCP were 804 and $439 \mu \mathrm{g}$ tyrosine equivalents per $30 \mathrm{~min}$ per $\mathrm{ml}$ of enzyme solution respectively. O, MAP; $\odot$, PCP.

Effect of temperature and $p H$ on $M A P$ and $P C P$

Both enzymes showed the same temperatureactivity curve (Fig. 4) and pH-activity curve. (Fig. 5)

Action of MAP and PCP on the oxidized $B$ chain of insulin

MAP and PCP hydrolyzed oxidized B

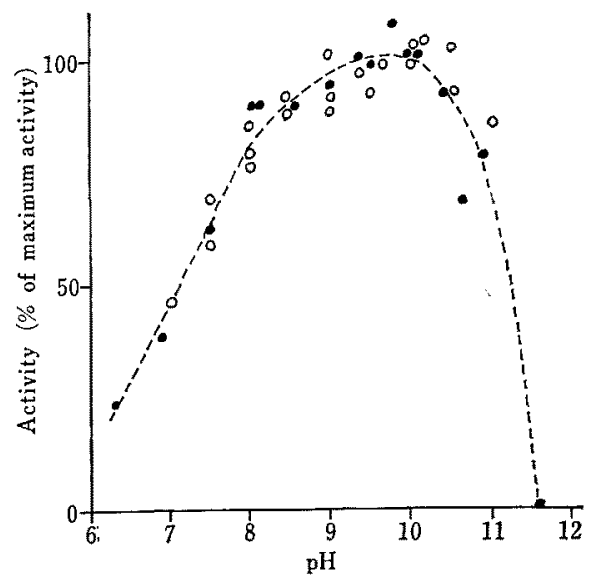

FIG. 5. pH-Activity Curve of MAP and PCP.

The enzyme activity was determined in the presence of $0.5 \%$ casein dissolved in $50 \mathrm{~mm} \mathrm{KH}_{2} \mathrm{PO}_{4}$, boric acid, glycine or $\mathrm{NaHCO}_{3}$ buffer. pH was adjusted with $\mathrm{NaOH}$. Maximum activity of MAP and PCP were 460 and $246 \mu \mathrm{g}$ tyrosine equivalents per $30 \mathrm{~min}$ per $\mathrm{ml}$ of enzyme solution respectively.

O, MAP; $\odot$, PCP.

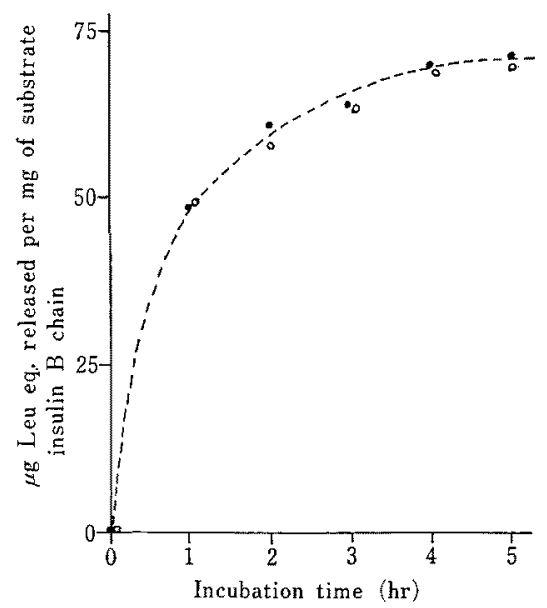

FIG. 6. Action of MAP and PCP on Oxidized B Chain of Insulin.

Equal volumes of MAP or PCP $(0.25 \mathrm{ml})$, water and oxidized $\mathrm{B}$ chain of insulin in $150 \mathrm{mM} \mathrm{NaHCO}_{3^{-}}$ $\mathrm{NaOH}$ buffer ( $\mathrm{pH}$ 9.5) were mixed and incubated for the time indicated in the figure. The increase in ninhydrin-positive material was determined as described in MAterials AND Methods.

O, MAP;, PCP.

chain of insulin as shown in Fig. 6. Both enzymes showed the same maximum hydrolysis rate. Three peptides were obtained in relatively large amounts and one peptide in small 


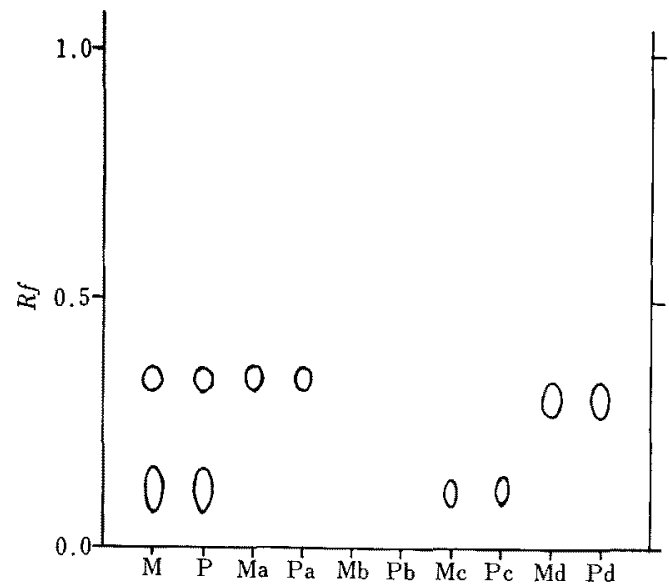

Fig. 7. Thin-layer Chromatography of Peptides Obtained after Hydrolysis of Oxidized B Chain of Insulin by MAP or PCP.

One dimensional thin-layer chromatography of peptides obtained from oxidized $B$ chain of insulin after hydrolysis with MAP or PCP. Peptides were deionized on a Dowex 50 WX2 column and eluted with $18 \%$ pyridine. One peptide remained in the column and was eluted with $2 \mathrm{~N} \mathrm{NH}_{4} \mathrm{OH}$. After chromatography, ninhydrin solution in $n$-butanol was sprayed.

M, Oxidized B chain of insulin after hydrolysis with MAP. The hydrolyzate was deionized as described in Materials and Methods and subjected to thin-layer chromatography; $\mathrm{P}$, Oxidized $\mathrm{B}$ chain of insulin after hydrolysis with PCP; Ma, Fraction a in Fig. 8 of $M$; Mb, Fraction $b$ in Fig. 8 of $M$. No spot was detected; Mc, Fraction c in Fig. 8 of $\mathrm{M}$; Md, The fraction not eluted from deionization column with $18 \%$ pyridine. This fraction was eluted with $2 \mathrm{~N} \mathrm{NH} \mathrm{NH}_{4} \mathrm{OH}$ and dried in vacuo in the presence of small amount of $\mathrm{NaOH}$. Therefore, this fraction is not included in $\mathrm{M}$; $\mathrm{Pa} \sim \mathrm{Pd}$, The corresponding fractions obtained from the hydrolyzate of oxidized $B$ chain of insulin with PCP.

amount (Fig. 7). One of these peptides was not eluted from the deionization column with $18 \%$ pyridine, but was eluted with $2 \mathrm{~N}$ $\mathrm{NH}_{4} \mathrm{OH}$. This peptide contained Thr, Pro, Ala, Phe, Tyr and Lys in practically equal molar amounts and was identified as peptide 25 30 (Table II). Two peptides were obtained in relatively large amounts and one peptide in small amount on fractionation of the hydrolyzate on a Dowex 50 WX2 (pyridine type) column (Fig. 8). First peak contained $\mathrm{CySO}_{3} \mathrm{H}$, Glu, Gly (2), Val, Leu, Phe and Arg. This peptide was identified as peptide $17 \sim 24$. Second peak contained $\mathrm{CySO}_{3} \mathrm{H}(2)$, Asp, Ser,
Table II. Amino Acid Composition of Peptides Ortained on Hydrolysis of Oxidized

B CHAIN OF INSULIN WITH MAP OR PCP

Peptides a, b, c are shown in Fig. 8. Peptide d was recovered from deionization column by elution with $2 \mathrm{~N} \mathrm{NH} \mathrm{NH}_{4} \mathrm{OH}$. Amino acids indicated in italic letters were not found after dinitrophenylation.

\begin{tabular}{|c|c|c|c|c|c|c|c|}
\hline \multirow[t]{2}{*}{$\begin{array}{l}\text { Amino } \\
\text { acid }\end{array}$} & \multicolumn{4}{|c|}{ MAP } & \multicolumn{3}{|c|}{$\mathrm{PCP}$} \\
\hline & $\mathrm{a}$ & $\mathrm{b}$ & $\mathrm{c}$ & $d$ & $a$ & $c$ & d \\
\hline $\mathrm{CySO}_{3} \mathrm{H}$ & 1.1 & 2.2 & 1.1 & & 1.0 & 1.0 & \\
\hline Asp & & 1.1 & 1.0 & & & 1.1 & \\
\hline $\begin{array}{l}\text { Thr } \\
\text { Ser }\end{array}$ & & 1.0 & 0.9 & 1.1 & & 0.9 & $1.0^{b)}$ \\
\hline Glu & 1.1 & 3.2 & 2.1 & & 1.1 & 2.1 & \\
\hline Pro & & & & 1.1 & & & 1.1 \\
\hline Gly & 2.1 & 3.2 & 1.1 & & 2.1 & 1.1 & \\
\hline Ala & & 1.3 & 1.1 & $1.0^{b)}$ & & 1.2 & 0.8 \\
\hline Val & 1.0 & $3.0^{b}$ & 1.9 & & $1.0^{5)}$ & $2.0^{b)}$ & \\
\hline Leu & $1.0^{b)}$ & 3.7 & $3.0^{b)}$ & & 1.1 & 3.1 & \\
\hline Tyr & & trace & 0.9 & 0.8 & & 0.6 & 1.1 \\
\hline Phe & 1.0 & $2.3^{a)}$ & 1.0 & 1.0 & 1.0 & 1.2 & 0.8 \\
\hline Lys & & & & 1.2 & & & 1.0 \\
\hline His & & 1.9 & 2.0 & & & 2.1 & \\
\hline Arg & 1.1 & 0.7 & & & 1.2 & & \\
\hline
\end{tabular}

a) Approximately half of this amino acid was recovered after dinitrophenylation.

b) Other amino acids were calculated on the molar basis of these amino acids.

Glu (3), Gly (3), Ala, Val (3), Leu (4), Phe (2), His (2) and Arg. A small amount of Tyr was also recovered. This peptide was identified as peptide 1 24. Peptide bond 16 17 was not hydrolyzed in this case, probably because Tyr16 was destroyed during preparation of oxidized B chain. Recovery of this peptide was $13 \%$ of the peptide $17 \sim 24$. Third peak contained $\mathrm{CySO}_{3} \mathrm{H}$, Asp, Ser, Glu (2), Gly, Ala, Val (2), Leu (3), Tyr, Phe and His (2). This peptide was identified as peptide $1 \sim 16$. Peptide $17 \sim 30$, which we expected to find, was eluted after the peptide $1 \sim 16$ when incompletely hydrolyzed B chain was applied to the column. However, in this experiment, the amount of peptide $17 \sim 30$ was very small and not found quantitatively. This means that peptide bond $24 \sim 25$ was hydrolyzed almost quantitatively in this experiment.

These results show that MAP and PCP cleave the same point of oxidized $B$ chain of 


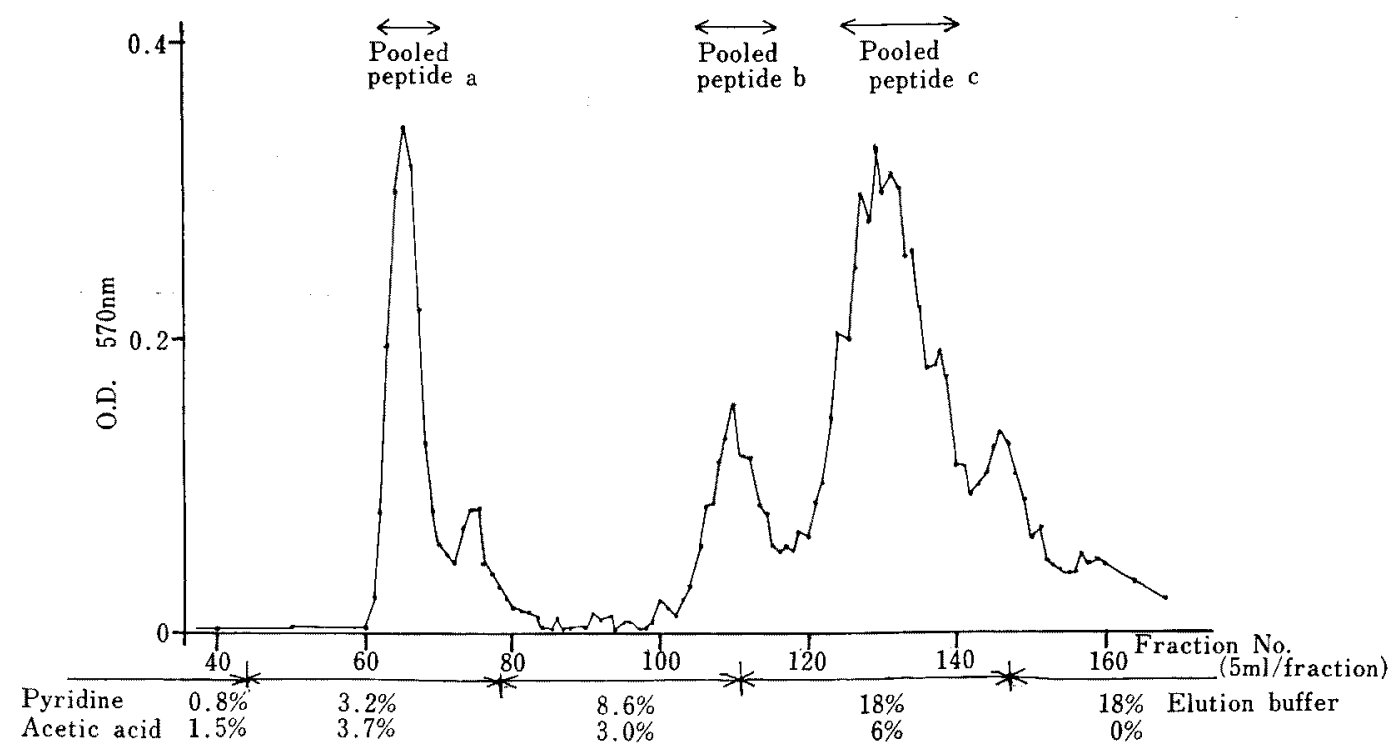

FIG. 8. Dowex 50 WX2 Column Chromatography of Hydrolyzate of Oxidized B Chain of Insulin.

Oxidized B chain of insulin was hydrolyzed with MAP for $3 \mathrm{hr}$ at $37^{\circ} \mathrm{C}$. The hydrolyzate was deionized and chromatographed on a Dowex $50 \mathrm{WX} 2$ (pyridine type) column. For details, see the text.

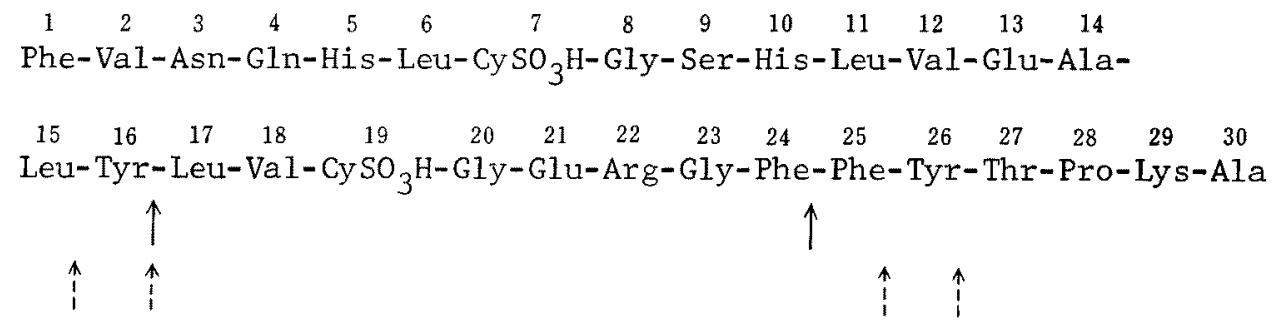

FIG. 9. Cleavage of Oxidized B Chain of Insulin by MAP, PCP and Chymotrypsin.

$\uparrow$, MAP and PCP; $\uparrow$, chymotrypsin. ${ }^{18)}$

insulin (Fig. 9). The specificity of these enzymes is similar to that of chymotrypsin as expected by inhibitor studies (carboxyl-side of aromatic amino acids). Chymotrypsin, MAP and PCP cleave peptide bond Tyr (16)-Leu (17). However, we could not find any evidence that MAP and PCP cleave peptide bonds Phe (25)-Tyr (26) or Tyr (26)-Thr (27) which are cleaved by chymotrypsin. ${ }^{18)}$ On the other hand, MAP and PCP cleaved peptide bond Phe (24)Phe (25) which is not cleaved by chymotrypsin. This specificity of MAP and PCP suggests these enzymes play an important role in vivo.

\section{DISCUSSION}

Some properties of MAP and PCP have been reported in this paper. Both enzymes showed very similar properties in many studies, i.e., molecular weight, substrate specificity, reaction with inhibitors, solubility, $\mathrm{pH}$-activity curve, and temperature-activity curve. Though the enzymes showed slightly different reaction with TPCK this may be due to the purity of the enzyme preparations. Further purification and characterization of the physicochemical properties of the enzymes should clarify the identity of both enzymes finally. At present, it is still very difficult to isolate sufficient MAP or PCP to study such physico- 
chemical properties as sedimentation-diffusion coefficients.

The origin of MAP still remains to be elucidated. Does MAP originate from mast cells in muscular tissue or from muscle cells themselves? The low population of mast cells and relatively high activity of the enzyme in this tissue may favor the latter assumption.

Recently Kominami et al, ${ }^{19 \prime}$ and Katunuma et al. ${ }^{201}$ purified a protease from rat skeletal muscle which shows very high specificity toward apoproteins of pyridoxal enzymes. It will be of interest in future study to compare the properties of MAP and their enzyme.

\section{REFERENCES}

1) T. Noguchi and M. Kandatsu, Agr. Biol. Chem,, 35, 1092 (1971).

2) D. Lagunoff and E. P. Benditt, Ann. New York Acad. Sci. . 103, 185 (1963).

3) Z. Darzynkiewicz and E. A. Barnard, Nature, 213, 1198 (1967).

4) G. C. Budd, Z. Darzynkiewicz and E. A. Barnard, ibid., 213, 1202 (1967).

5) J. Kawiak, W. H. Vensel, J. Komender and E. A.
Barnard, Biochim. Biophys. Acta, 235, 172 (1971).

6) W. H. Vensel, J. Komender and E. A. Barnard, ibid, 250, 395 (1971).

7) 1. Pastan and S. Almquist, J. Biol. Chem., 241, 5090 (1966).

8) I. Pastan and S. Almquist, Endocrinol., 78, 350 (1966).

9) I. Pastan and S. Almquist, ibid, 78, 361 (1966).

10) O. H. Lowry, N. J. Rosebrough, A. L. Farr and R. J. Randall, J. Biol. Chem., 193, 265 (1951).

11) P. Andrews, Biochem. J., 91, 222 (1964).

12) T. Noguchi, Doctor Thesis, The University of Tokyo (1970).

13) T. O. Baldwin and A. Riggs, J. Biol. Chem., 249, 6110 (1974).

14) F. Sanger, Biochem. J., 44, 126 (1949).

15) E. W. Yemm and E. C. Cooking, Analyst, 80, 209 (1955)

16) K. Titani and Y. Yaoi, Tampakushitsu Kakusan Koso, 10, 250 (1965).

17) K. Iwai and H. Fujioka, ibid., 8(5), 5 (1963).

18) F. Sanger and H. Tuppy, Biochem. J., 49, 481 (1951)

19) E. Kominami, K. Kobayashi, S. Kominami and N. Katunuma, J, Biol. Chem., 247, 6848 (1972).

20) N. Katunuma, E. Kominami, K. Kobayashi, Y. Banno, T. Shiotani, K. Suzuki, K. Chichibu, Y. Hamaguchi and T. Katsunuma, European $J$. Biochem., 52, 31 (1975). 